\title{
STATE CONTROL, IN ACCORDANCE \\ WITH THE INTERNATIONAL PRACTICE, OVER MARKETING OF IMPORTED CONSUMER PRODUCTS
}

\author{
Khyzhniak V. O.
}

\section{INTRODUCTION}

At the current stage of development of the Ukrainian society, when Ukraine has to begin new administrative reforms, considering that Ukraine is ready and willing to be a legally competent member of the European community, the study of the international experience associated with the state control over marketing of imported consumer products is of high priority.

The national policy of Ukraine in the area of the state control of consumer products and of consumer protection is focused on the improvement of existing laws, implementation of European directives, coordination of national standards with international and European standards as normative documents designed for verifying the compliance of products with the specified requirements, arrangement of conditions for activities of enterprises and companies in the area of the state control over marketing of consumer products, and improvement of the existing consumer protection system.

\section{Analysis of recent publications and studies}

The problems in the area of the state control of the safety and quality of consumer products and in the area of consumer protection have been studied by such Ukrainian researches as Mandybura V.O., Zakhozhai V.B., Vitkin L.M., Hryshova I.Y., Prytulska N.V., Yazvinska O.M., Nehodenko V.S., Mytiai O.V., Stoianova-Koval S.S., Malyk M.Y., Paskhaver B.Y., and Sabluk P.T. Nevertheless, there are many existing scientific, organizational, and economic problems in this area which should be studied.

According to the opinion of Vitkin L.M., the elements required for the functioning of an efficient sate control system are the availability of proper legislative and normative acts, allocation of responsibility of controlling institutions, enhanced control of risk-bearing products, availability of incentives for ensuring the safety and quality of products, availability of sufficient information support, and availability of qualified state inspectors. Nevertheless, there is a need to further study the problems associated with 
the state control, according to the international practice, over marketing of imported consumer products.

\section{Study objective}

The study objective is to create, on the basic of the international experience, a modern efficient system for controlling consumer products and providing consumer protection in compliance with the requirements of the Ukrainian economy and consumers and for promoting business activities in Ukraine.

\section{Ukraine}

\section{Study results}

One of the important tasks in reforming the system for controlling consumer products and providing consumer protection according to the international practice is the implementation of a product marketing control system. This system is designed for ensuring the compliance of marketed products with the requirements of standards and normative documents relating to the safety of the products in terms of population health and public interests. Marketing of hazardous products is prevented by implementation, into national legislation, of EU regulations and directives, specifically Regulations No. 765/2008 of July 9, 2008 and Directive 2001/95/EC of December 3, 2001, which relate to the general safety of products, approved by the European Parliament and the European Commission.

The implementation of such normative documents became possible due to the adoption, in 2011, of such laws of Ukraine as the Law on the State Marketing Control and Nonfood Product Control ${ }^{2}$ and the Law on General Safety of Nonfood Products ${ }^{3}$. In accordance with these laws, products which do not comply with the specified requirements or are hazardous for public health are removed from the market. If infringing or faulty products are detected, the corresponding customs and law enforcement authorities should be immediately unformed.

The food product control functions are performed by the newly established State Service on Safety of Food Products and Consumer Protection. The nonfood product control functions are performed by the agencies authorized in accordance with the order of the Cabinet of Ministers of Ukraine on approval of the list of the state product marketing control

${ }^{2}$ Про державний ринковий нагляд і контроль нехарчової продукції; Закон України, 02.12.2010, № 2735-V; zakon.rada.gov.ua/laws/show/2735-17

3 Про загальну безпечність нехарчової продукції; Закон України, 02.12.2010 № 2736-VI; http://zakon.rada.gov.ua/laws/show/2736-17 
agencies and allocation of their responsibility» ${ }^{6}$. At the present time, the state product marketing control in 40 areas of responsibility is provided by 10 control agencies forming an integrated control system.

The product control functions when the products enter the custom territory of Ukraine are performed by customs authorities. If inconsistent products are detected at the border customs station, the corresponding state control agency should be unformed. It should be noted that customs control is mandatory only for such imported nonfood products which are declared as products to be subject to customs control or other control specified for products to be freely marketed in Ukraine ${ }^{7}$.

These factors have different effect on the structure and functions of agencies for performing imported product control in different countries.

\section{United States of America}

The main federal agency for controlling internal trade in USA is the Federal Trade Commission.

The Commission is an independent state authority established in 2014 for performing trade control functions and preventing anticompetitive practice. The Commission also controls the compliance of individuals and legal parties with the federal laws and regulations relating to consumer protection and competition.

The Commission acts on the basis of the Federal Trade Commission Act of 1914 (see Section 15, Items $41 \ldots$ 48, of the USA Federal Code). In accordance with the federal laws and regulations, the Commission has the rule-making powers and the right to use enforcement methods for ensuring the compliance of the internal trade with the requirements of federal laws and regulations concerning internal trade activities, for example, by filing claims to federal jurisdiction courts.

The list of normative documents (about 80 documents) issued by the Commission is presented in Part 1, Section 16, of the Federal Normative Acts Code.

Additionally to administrative functions, the Commission provides consultation services, supports reporting, and renders recommendations and advices for other governmental authorities.

Another independent authority that directly affects internal and external trade activities in USA, is the USA Consumer Product Safety Commission.

${ }^{6}$ Про затвердження переліку органів державного ринкового нагляду та сфер їх відповідальності; Постанова Кабінету Міністрів України, 01.06.2011, № 573; zakon2.rada.gov.ua/laws/show/573-2011-п

7 Віткін Л.М. Вдосконалення державного ринкового нагляду за безпечністю нехарчової продукції відповідно до європейських підходів; Л. Віткін: Стандартизація, сертифікація, якість, 2012, № 5, с. 18-25. 
The Commission protects consumers from hazards possible due to using domestic or foreign consumer products of poor quality. The Commission controls about 15 thousand product names.

According to the Commission estimates, losses induced by such events as illness, injury, or death or by damage of property due to using consumer products of poor quality in USA are about 800 billion dollars per year. The Commission activities in controlling the quality of such nonfood products as toys, fasteners, tools, cigarette lighters, household chemistry products, and other products allow the number of such events to be reduced to 30 percent during the recent 30 years.

The control of imported consumer products in USA is accomplished with consideration for energy saving and handling safety.

With consideration for energy saving, the consumer products are classified as follows:

1. Household appliances

For household appliances, the Energy Policy and Energy Conservation Act specifies applicable standards and regulations related to marking household appliances in connection with energy saving. The Codes and Standards Division of the USA Department of Energy is responsible for testing household appliances for compliance with the specified standards and regulations. The Control Division of the Federal Trade Commission controls marking of household appliances. The aforementioned Act applies to such household appliances as refrigerators, freezers, air conditioners, water heaters, ovens, dishwashers, laundry washers, driers, and other devices.

2. Commercial and industrial equipment

The aforementioned governmental authorities control the certification of commercial and industrial equipment. The categories of such equipment with consideration for handling safety are the following:

a) Toys and other products for children

b) Lead-containing paints

c) Bicycles and helmets for bicyclists

d) Fireworks

e) Combustible textiles

f) Decorative materials

g) Cigarette lighters

h) Other materials and devices

The categories of imported household electronic devices subject to certification are the following:

a) Devices generating electromagnetic or acoustic radiation, such as television sets, microwave cookers, X-ray units, ultrasonic therapy equipment, mobile telephone sets, and other devices 
These devices should be certified in accordance with the Law on Food Products, Drugs, and Cosmetics. The controlling authority for these devices is the Radiological Safety Center of the USA Food and Drug Administration (FDA).

b) Radio frequency devices such as radio receivers, radio transmitting devices, radio recorders, and other devices

The certification of these devices is accomplished by the USA Federal Communications Commission.

\section{Great Britain}

In Great Britain, there is no direct control over internal marketing of imported consumer products, and such products are controlled in accordance with the general requirements for internal marketing control, specifically, in accordance with the requirements of the Goods Trade Act (1979), which also applies to consumer protection, as well as the Goods and Services Supply Act (1982), the Consumer Protection Act (1987), and the Regulations for Consumer Protection in Remote Marketing (2000). All these acts are focused on responsibility for the quality of the consumer products and for consumer safety.

\section{Germany}

In the Federal Republic of Germany, control in the area of external trade is accomplished by the Federal Service for Economy and Export Control and, in special cases, by the Ministry of Economy and Technology, the Ministry of Food, Agriculture, and Consumer Protection, the Ministry of Transport, Construction, and Housing, the Ministry of Finance, and the German Central Bank. Licenses for performing export and import operations in accordance with the Law on External Economic Activity are issued by the Ministry of Economy and Technology, the Ministry of Food, Agriculture, and Consumer Protection, the Ministry of Finance, and the German Central Bank. Licenses may be individual or general.

The Law on Customs Management supplements and specifies the customs legislation documents of the European Union and, specifically, specifies the organizational structure and functions of the system for controlling and registering product flows. This Law specifies for the Customs Service, which is subject to the Ministry of Finance, additionally to fiscal tasks, powers to control export and import operations and issuance of licenses, to perform the functions of the state internal market regulation, and to control the compliance of products with the specified sanitary and veterinarian requirements.

The consumer products imported from countries, which are not members of the European Union, to the Germany for internal consumption are subject to customs clearance within a specified period of time. 
In order to diminish load on the border customs stations, customs clearance procedures are performed at internal customs stations after the corresponding preliminary customs procedures had been performed at the border customs stations. After the customs procedure at the border customs station had been performed, the products can be transported from the border customs station to the internal customs station according to the customs mode provided for internal transport operations. When the customs clearing procedure for the products at the internal customs station has been performed, the products are free for marketing, provided that the following conditions are met:

1. The customs declaration and accompanying documents (invoices, transport documents) have been submitted.

2. The customs declaration has been approved by the customs station.

3. The documentation and products have been inspected, and the corresponding report on the inspection results has been prepared.

4. The amount of import duty and payment terms have been determined.

5. The corresponding payments have been effected.

Additionally to the customs law, depending on the product characteristics, it is necessary to consider laws and regulations concerning market relations, origin of the products, external economic activity, and health care.

In the European Union, the cost of imported products is determined in accordance with the General Agreement on Tariffs and Trade Code for Determining Customs Value. The amount of customs duty is determined with consideration for the contract according to which the products have been imported. If the customs value cannot be determined, one of the following five methods for determining the estimated cost of the imported products should be used:

1. The method based on the cost of the products specified in the contract

2. The method based on the cost of the products in accordance with the contract for supply of similar products

3. The method based on deduction of amounts

4. The method based on addition of amounts

5. The method based on determining the final estimated cost

According to Article 32 of the General Agreement on Tariffs and Trade, if the cost of products is underestimated, for example, in order to evade the payment of customs duty, the underestimated cost amount should be increased by the difference between the estimated cost amount determined by using the aforementioned method and the cost amount specified in the contract.

Activities in the area of customs and pricing policy are controlled by the Ministry of Economy and Technology, which is responsible for coordinating 
the policy with the corresponding authorities of the European Union. The internal control of imported products supplied from countries which are not members of the European Union is accomplished by the Ministry of Finance with the subordinate Customs Service.

\section{France}

The basic normative legal documents for controlling the marketing of consumer products in France are the International Agreement of the European Union with the additional French codes, such as the Customs Code, the Trade Code (in relation to competition law), the Consumption Code, the Code for Agreements Concluded by Governmental Authorities, the Health Protection Code, the Social Protection Code, the Labor Protection Code, the Construction Code, and the Intellectual Property Code.

The general requirements concerning the marketing of products within the European Union are contained in EU New Approach Directive, which was approved by the European Commission in 1985 and is based on the following conditions:

1. There are national normative legal documents concerning special safety requirements in countries which are members of the European Union.

2. Only such products which comply with special safety requirements are allowed to be freely marketed in the European Union.

3. The corresponding European institutions are responsible for developing technical specifications for products in accordance with the European normative legal documents.

4. The technical specifications for products are not mandatory if the product manufacturer use production equipment and processes which ensure the compliance of the products with the specified requirements.

5. The compliance of products with the Directive requirements should be confirmed by the corresponding authorized governmental authorities.

For implementing this Directive, in is necessary to intensify control and coordination of market activities and to provide the mandatory identification of the product manufacturer, storage of the information concerning the marketing of products, and availability of licenses required in the European Union.

Interaction and cooperation in connection with the internal marketing of products is accomplished via the European information system (RAPEX) designed for controlling marketing of all potentially hazardous products, excluding food products, pharmaceutical products, and medical-care products. This system provides the possibility to exchange information, concerning potentially hazardous products, between the European Commission and members of the European Union. The RAPEX system provides the possibility to collect information on actions of the national control authorities, product manufacturers, and product distributors. Every 
Friday, the list of potentially hazardous products is published according to the data submitted by the national control authorities. This list contains all the information on products, including the information on potential hazards in connection with the products and on actions performed by the corresponding national controlling authorities in response to such information.

Control over marketing of consumer products is accomplished by the General Directorate for Customhouses and Indirect Taxes (Direction Générale des Douaneset Droits Indirects) and the General Directorate for Competition, Consumption, and Reaction against Illegal Trade (Direction générale de la Concurrence, de la Consommation et de la Répression des Fraudes) with authirazed agencies in France. The comtrol begins at the stage of customs clearance of the ptoducts. The importer shoult submit the corresponting declaration to the customs agency of the General Directorate for Customhouses and Indirect Taxes. The customs agency, in accordance with the declaration, should verify the compliance of the products with the requirements of the national legislation and EU regulations. If the customs authority has permitted import of the product to France, the customs agency should issue a quality certificate for the products. If the verification results are controversial, the customs agency may require the product samples for testing the samples in the appropriate laboratory of the General Directorate for Competition, Consumption, and Reaction against Illegal Trade.

The authorized agencies of the General Directorate for Competition, Consumption, and Reaction against Illegal Trade control all processes in relation to the manufacture, import, and distribution of products.

The most intensive activities of the General Directorate are in connection with plant products subjected to risk of pesticide contamination, as well as with potentially hazardous products for children, sports, or entertainment.

The control of quality and safety of products, including imported products, marketed in France, is based on the testing and expert examination of the products in laboratories of the General Directorate by performing the following activities:

1. Analysis

2. Scientific and technical support

3. Additional studies

The General Directorate for Customhouses and Indirect Taxes and the General Directorate for Competition, Consumption, and Reaction against Illegal Trade jointly control marketing of imported products and ensure the testing of such products if the products do not comply with the specified quality requirements. Defective or hazardous products are removed from the market and disposed. Enterprises which allowed the marketing of such products are subject to administrative or criminal responsibility. 


\section{Brazil}

According to the information presented by the Brazil Ministry of Development, Industry, and External Trade, there is no special mode of control over the marketing of imported products in Brazil. The marketing of imported products, after all customs procedures had been performed, is accomplished in the same manner as the marketing of national products.

It should be noted that every importer in Brazil is subject to registration with the governmental agency relating to external trade, that is, with the External Trade Secretariat of the Ministry of Development, Industry, and External Trade. The importer data are entered into the SISCOMEX data base.

The operations required for customs clearance of imported products are the following:

1. Licensing the products (only products of special categories).

2. Registering the customs declaration for the products with the corresponding customs authority.

3. Performing customs inspection of the products as follows:

a) inspection of products of special categories only (green level inspection);

b) inspection of the accompanying documents for the products (yellow level inspection);

c) inspection of the accompanying documents and physical control of the products (red level inspection);

d) inspection of the accompanying documents and physical control of the products, and additionally, the detailed analysis of the products, for example, in order to determine the customs value of the products or the compliance of the products with the Brazil law requirements (gray level inspection).

4. Performing the customs clearance procedure, including payment of customs fees.

5. Transporting the products to the specified destination points.

In accordance with the Consumer Protection Law, the importer is responsible for the quality of the imported products. The marketing of any consumer products in Brazil is permitted only if the products comply with the requirements of the national standards and normative documents, relating to the composition, marking, and packing of the products, specified by the National Institute for Metrology, Standardization, and Product Quality Assurance which is in the area of responsibility of the Ministry of Development, Industry, and External Trade. The products should be marked with information, in Portuguese, on the composition, production date, and pull-date of the products. The National Institute also controls activities in connection with the certification of imported products and maintains the list of products and services which are subject to mandatory certification. 


\section{Canada}

The control of exported and imported products in Canada is based on the federal and provincial laws and regulations. Import of most products to Canada is possible without special permits, except some special products (about 70 product names), import of which is limited. The Import Control List and the Export Control List are compiled by the federal government in accordance with the Export and Import Permit Act. The importer should apply to the Ministry of Foreign Affairs and International Trade with a request for obtaining an import permit. Some products are imported on the basis of special documents made out by some federal authorities (the Ministry of Agriculture and Food Products, the Ministry of Fishing Industry and Ocean Resources, and other authorities). In this case, the control of exported and imported products is accomplished in accordance with the Meat Inspection Act, the Fishery Product Inspection Act, the Plant Product Inspection Act, the Plant Quarantine Regulations, and other regulatory documents.

The imported products subject to control include textile products, clothing, agricultural products, metals, arms, and ammunition. Other imported products are not subject to control and do not require special import permits.

For imported products which are not subject to control, an internal import certificate may be required. This certificate is a guarantee document which confirms that the Canada government permits import of the products by the declared importer.

Imported products must comply with the Canadian regulations for marking such products and with requirements for labels on imported products.

Imported products are marketed in Canada in accordance with the corresponding federal and provincial regulatory documents in the same manner as products of national origin,

The basic federal authority in Canada responsible for controlling safety of marketed consumer products is the Ministry of Health. The Ministry specifies the maximum allowed content of toxic substances, such as lead, cadmium, mercury, and other substances. in consumer products and in products potentially hazardous for the environment.

In order to improve the safety of imported products, the Ministry cooperates with the Canadian Frontier Service in detecting potentially hazardous imported consumer products.

\section{South Korea}

In the 1960s, the Republic of Korea adopted the export-oriented strategy of economic development, which requires the transparency of the national 
economy and integration of Korea into the international economic community.

The state sector of economic activities in Korea holds a leading position in the economy of Korea and is strictly controlled by the government.

Since 1970s, the following 7 industries have been emphasized by the special laws as top-priority industries: mechanic engineering, electronic engineering, textile industry, iron and steel industry, nonferrous-metals industry, petroleum chemistry, and shipbuilding industry. These industries have preferential access to resources and tax exemptions.

The state control of product quality is provided in the primary areas of product export.

The strict state control is provided for foreign investments. It should be noted that direct foreign investments in $1967 \ldots 1986$ were less than 2 percent of the total domestic investments. Korea attracts only such inward investments which comply with the adopted strategy of economic development. Therefore, not less than two thirds of foreign investments are concentrated in petroleum chemistry, mechanic engineering, and electronic engineering.

Korea actively uses import customs duties in order to protect its national producers and promote export of products. The customs duties are 5 ... 20 percent of the product cost for raw products and industrial products which are not produced in Korea, $25 \ldots 60$ percent for raw products and industrial products which are produced in Korea, and $80 \ldots 150$ percent for raw products and industrial products which are not essential for the Korea economy. In some cases, raw products which are essentially required for the areas of product export are released from customs duties. The state controls import activities also by limiting issuance of import licenses.

The Korean economy significantly depends on external trade. The part of external trade with China was 2.9 percent in 1991, when the system for analyzing statistical data characterizing the dependence of economy on external trade was implemented, and 10.8 percent in 2001. In this regard, China was ahead of Japan in 2003 and USA in 2004 and became the largest trade partner of Korea. Due to this, the dependence of the Korean export on trade with China increased significantly. The export volume in the trade of Korea with China was 1 billion US dollars in 1991 and increased to 86.7 billion US dollars in 2009. The part of export trade with China was 1.39 percent in 1991 and increased to 23.85 percent in 2009. Over the same period of time, the cost of products imported from China to Korea increased from 3.4 billion US dollars to 52.3 billion US dollars (from 4.32 percent to 16.79 percent).

The stably high rates of economic growth in China changed the structure of the Korean external trade, specifically, due to the increase of the volume 
of trade on the give-and-take basis, according to which Korea exports raw products and semi-finished products to China and imports final products from China. The part of export trade on the give-and-take basis was about 10 percent of the total export trade of Korea with China in 2004 and increased to 24 percent in 2009. At the present time, the part of import trade on the give-and-take basis is about 12 percent.

It should be noted that the free trade agreements concluded by Korea with some countries provide for relaxation in requirements for custom charges and tariffs for importers.

Before the 1980s, the trade policy of Korea was focused on increase of export and control of import, as the Korean economy was characterized by the trade balance deficit and lack of foreign exchange. At the end of 1980s, Korea revised its trade policy in order:

a) to actively participate in the formation of the new international trade system, specifically, within the limits of the Uruguay Round of the General Agreement on Tariffs and Trade (GATT), and in the international economy;

b) to provide the implementation of the national program for cancellation of restrictions on imports and other programs promoting the market stabilization;

c) to remove obstacles for investments and, as a result, to promote access to the Korean market.

In October 1989, the Korea government terminated one-sided restrictions on imports, which were provided in accordance with Article XII of the GATT, and agreed to gradually cancel the restriction to June 1997.

In March 1991, Korea presented the plan for the first stage of liberalization of imports for 1992, 1993, and 1994, according to which Korea provided a free trading mode for 43 product names. The level of liberalization of imports was 98.8 percent in 1994, after providing a free trading mode for additional 47 product names, 99.9 percent at the end of 1999, and 100 percent in 2001,

Since 1983, the customs duties in Korea had been reduced gradually from 23.7 percent in 1983 to 10.1 percent in 1992. Over the same period of time, the customs duties for industrial products had been reduced from 22.6 percent to 8.4 percent. In accordance with the system of customs privileges and import quotas, significantly lower customs duties were provided for products in which Korea was interested.

From January 1988, customs privileges were granted to 319 products, including beauty products, construction equipment, electronic devices. and cars. Import quotas were granted to 35 products, including cereal products, unrefined sugar, and refined sugar.

Since July 1988, import quotas tariffs for 691 products (391 raw products and 300 consumer products) has been reduced by 8.5 percent. 
Table 1

Implementation of preferential customs duties in Korea

\begin{tabular}{|c|c|c|c|c|c|c|c|c|}
\hline \multirow{2}{*}{$\begin{array}{c}\text { Product } \\
\text { code }\end{array}$} & Product & \multicolumn{7}{|c|}{ Customs duty (\%) } \\
\cline { 3 - 9 } & Live pigs & 20.9 & 19.7 & 18.6 & 18.0 & 18.0 & 18.0 & 18.0 \\
\hline 0303 & $\begin{array}{c}\text { Frozen fish } \\
\text { (salmon) }\end{array}$ & 10.0 & 10.0 & 10.0 & 10.0 & 10.0 & 10.0 & 10.0 \\
\hline 0401 & Milk and cream & 41.7 & 39.4 & 37.1 & 36.0 & 36.0 & 36.0 & 35.0 \\
\hline 0803.00 & Fresh bananas & 95.0 & 93.0 & 91.0 & 90.0 & 90.0 & 90.0 & 90.0 \\
\hline 1513.11 & Crude coconut oil & 28.5 & 27.9 & 27.3 & 27.1 & 27.0 & 27.0 & 27.0 \\
\hline 2009.60 & Grape juice & 47.5 & 46.5 & 45.5 & 45.0 & 45.0 & 45.0 & 44.0 \\
\hline 2901.10 & Butane & 5.0 & 3.0 & 1.0 & 0 & 0 & 0 & 0 \\
\hline 2930 & $\begin{array}{c}\text { Organosulfur } \\
\text { compounds }\end{array}$ & 13.3 & 10.6 & 7.9 & 6.5 & 6.5 & 6.0 & 5.5 \\
\hline 3006 & $\begin{array}{c}\text { Pharmaceutical } \\
\text { products }\end{array}$ & 9.4 & 3.1 & 0 & 0 & 0 & 0 & 0 \\
\hline 3303.00 & $\begin{array}{c}\text { Perfumery } \\
\text { products }\end{array}$ & 28.8 & 24.4 & 19.9 & 15.4 & 11.0 & 6.5 & 3.5 \\
\hline 4001.10 & Natural latex & 2.0 & 2.0 & 2.0 & 2.0 & 2.0 & 2.0 & 2.0 \\
\hline 5201.00 & Cotton & 6.0 & 4.4 & 2.8 & 2.5 & 2.0 & 2.0 & 2.0 \\
\hline 6103.11 & Suits of clothes & 35.0 & 35.0 & 35.0 & 35.0 & 35.0 & 35.0 & 35.0 \\
\hline 7206.10 & $\begin{array}{c}\text { Iron and steel in } \\
\text { ingots }\end{array}$ & 5.0 & 3.0 & 1.0 & 0 & 0 & 0 & 0 \\
\hline 8527.21 & Optical fibers & 16.0 & 16.0 & 16.0 & 16.0 & 16.0 & 16.0 & 16.0 \\
\hline 9001.10 & Radio receivers & 8.0 & 8.0 & 8.0 & 8.0 & 8.0 & 8.0 & 8.0 \\
\hline 8421.11 & Cream separators & 13.0 & 13.0 & 13.0 & 13.0 & 13.0 & 13.0 & 13.0 \\
\hline 9701.10 & $\begin{array}{c}\text { Pictures, } \\
\text { drawings }\end{array}$ & 0 & 0 & 0 & 0 & 0 & 0 & 0 \\
\hline
\end{tabular}

In December 1991, the National Assembly of Korea ratified the agreements of the Uruguay Round of the GATT.

\section{Japan}

In accordance with the legislation of Japan, all imported products are subject to control and cannot be used in Japan without certification in accordance with the specified normative documents, which are classified as mandatory standards and regulations and optional standard and regulations. The compliance of products with the specified normative documents is verified by the National Engineering Assessment Institute and the National the National Science and Technology Institute on request of the Ministry of Economy, Science, and Technology based on the application of the supplier, manufacturer, or importer of the products.

The state authority responsible for the standardization of products in Japan is the Industrial Standards Committee, which renders consultation services to the Ministry of Economy, Science, and Technology. The Committee is responsible for more than 600 industrial products and maintains more than 8500 standards. The tasks of the Committee are to 
establish and support regional industrial standards committees, to control processes of product certification, to participate in the development of international standards, and to promote the implementation of standardization systems. Since 1996, the Committee has been exchanging information with European standardization agencies, specifically, with the European Committee for Electrical Standardization (CENELEC).

Any enterprise in Japan has no right to manufacture, import, or sell appliances without proper marking in accordance with the existing standards. Application of labels to imported appliances is allowed only after permission to import the appliances is obtained, and if required, after factory inspection of the quality of the appliances.

The Law on Appliances and Material Safety, the Law on Product Safety, and the Civil Cote of Japan require that transport documents for imported products must contain detailed information on the products. According to the legislation of Japan, labeling of appliances and other consumer products is mandatory.

According to the Law on Appliances and Material Safety, the Ministry of Economy, Science, and Technology has the right to authorize its representatives to inspect offices, factories, workplaces, shops, warehouses, and product documentation. Hazardous products detected are not permitted to be marketed in Japan.

Before obtaining the permission to market appliances, the supplier must inspect the appliances for compliance with the specified requirements in accordance with the Regulations for Appliances and Materials approved by the Ministry of Economy, Science, and Technology. If the appliances comply with the requirements and are approved by the Ministry, the supplier, manufacturer, or importer of the appliances has to pay appropriate charges in connection with the inspection. The information on the appliances should be published in the official journal of the Ministry.

The Ministry of Economy, Science, and Technology permits marketing of appliances only if the appliances comply with the specified ISO and IEC standards.

\section{CONCLUSIONS}

For further improvement of the consumer protection system, it is necessary to tighten control of the quality and safety of products and ensure the compliance of products with the requirements of national and international standards, laws of Ukraine, and regulations of the European Union. The activities in connection with this are the following:

1. To carry on negotiations and conclude bilateral agreements with trade partners of Ukraine in order to prevent illegal import and marketing of products. 
2. To improve customs control in order to prevent import of products hazardous for human health and the environment.

3. To control the characteristics and origin of the products declared at the delivery of the products.

4. To implement information technologies and more intensively use electronic equipment for information processing.

5. To restructure the customs control system by:

- concluding bilateral agreements with countries which are members of the World Trade Organization (WTO);

- increasing the level of equipment support and providing certification of testing laboratories in accordance with the requirements of international standards;

- implementing regulations and standards in accordance with the Law of Ukraine on the State Marketing Control and Nonfood Product Control ${ }^{4}$.

\section{SUMMARY}

This paper deals with the international practice and approaches in connection with the organization and implementation of the state control over marketing of imported consumer products. It analyzes the main problems in the area of the state control of consumer products and consumer protection in Ukraine in order to promote the modernization of the Ukrainian economy and improve the quality and safety of consumer products.

\section{REFERENCES}

1. Про захист прав споживачів; Закон України, 12.05.199, № 1023-XII; zakon.rada.gov.ua/laws/show/1023-12

2. Про державний ринковий нагляд і контроль нехарчової продукції; Закон України, 02.12.2010, № 2735-V; zakon.rada.gov.ua/laws/show/2735-17

3. Про загальну безпечність нехарчової продукції; Закон України, 02.12.2010, № 2736-VI; http://zakon.rada.gov.ua/laws/show/2736-17

4. Про відповідальність за шкоду, завдану внаслідок дефектності продукції; Закон України, 19.05.2011, № 3390-V; zakon.rada.gov.ua/laws/ show/3390-17

5. Про основні принципи та вимоги до безпечності та якості харчових продуктів; Закон України, 22.07.2014, № 1602-VII; http://radakmu.org.ua/uploads/file/-/280915_01.pdf.

6. Про затвердження переліку органів державного ринкового нагляду та сфер їх відповідальності; Постанова Кабінету Міністрів України, 01.06.2011, № 573; zakon2.rada.gov.ua/laws/show/573-2011-п

\footnotetext{
${ }^{4}$ Про відповідальність за шкоду, завдану внаслідок дефектності продукції; Закон України, 19.05.2011, № 3390-V; zakon.rada.gov.ua/laws/show/3390-17 
7. Віткін Л.М., Вдосконалення державного ринкового нагляду за безпечністю нехарчової продукції відповідно до європейських підходів; Л. Віткін: Стандартизація, сертифікація, якість, 2012, № 5, с. 18-25.

8. Наумов О.Б., Свтушенко Є.О., Проблеми та шляхи підвищення ефективності споживання ресурсів у Херсонській області; Економічний простір: Збірник наукових праць. 22/2, ПДАБА, 2009, с. 108-115.

9. Притульська Н.В., Система захисту прав споживачів в Україні: проблеми реформування; Н. Притульська: Товари і ринки, 2015, № 2, c. $5-16$.

10. Гнатьєва Т.М., Вплив соціальної відповідальності бізнесу на конкурентоздатність підприємств аграрного сектора; Т.М. Гнатьєва, O.В. Ніколюк: Вісник Чернігівського державного технологічного університету, 2014, № 4(76), с. 151-158.

11. Gryshova I.Y., Stability of the competitive position of the agricultural sector in Ukraine at internal and external markets; І.Ю. Гришова, О.В. Митяй, В.В. Кужель: Актуальні проблеми економіки, 2016, № 3(177), с. 66-73.

12. Захожай В.Б., Управління якістю; В.Б. Захожай, Н.Г. Салухіна, О.М. Язвінська, А.Ю. Чорний, за науковою редакцією В.Б. Захожая: Навчальний. посібник для студентів вищих навчальних закладів, Видавничий дім «Персонал», 2011, 936 с.

13. Мандибура В. О., Особливості формування інституту довіри в системі забезпечення якості споживання та захисту прав споживачів; В. О. Мандибура, С. Г. Батажок: Вісник Інституту економіки та прогнозування, 2009, № 1, с. 69-73.

\section{Information about the author:} Khyzhniak V. O.,

Candidate of Economic Sciences, Director of the State Enterprise «Research Institute of Building Production named of V. S. Balitsky» 51, Lobanovskyi ave., Kyiv, 03110, Ukraine 